\title{
Karakterisasi Sifat-Sifat Fisik dan Mekanik Edible Film Pati Ganyong (Canna edulis Kerr.)
}

\author{
Physical and Mechanical Characteristics of Edible Film from Ganyong Starch (Canna \\ edulis Kerr.)
}

Arif Wijoyo $^{1}$, F. Sinung Pranata ${ }^{1 *}$, P. Kianto Atmodjo ${ }^{1}$

Fakultas Biologi Universitas Atma Jaya Yogyakarta, Jl. Babarsari No. 44, Yogyakarta 55281

E-mail: sinung@mail.uajy.ac.id.*Penulis untuk korespondensi

\begin{abstract}
This research was carried out in order to reveal ganyong starch's potential as a major ingredient of edible film, to understand the optimum concentration of ganyong starch and palmitic acid in the making process of edible film and to study their physical and chemical characteristics. The research has two stages, which were the starch preparation, and edible film preparation by using various concentrations of ganyong $\operatorname{starch}(1,2,3$, and $4 \% \mathrm{w} / \mathrm{v})$ and palmitic acid $(1,2,3$, and $4 \% \mathrm{w} / \mathrm{w})$. First research stage revealed that ganyong starch has a potential as a major ingredient of edible film because of its high amylose content $(32.53 \%$ on dry basis). The next stage of the research showed that the optimum ganyong starch concentration of edible film was $2 \%(\mathrm{w} / \mathrm{v})$. This concentration gives the WVTR (Water Vapor Transmission Rate) measurement of $11.86\left(\mathrm{~g} . \mathrm{mm} / \mathrm{m}^{2}\right.$. hour), film elongation of $2.26 \%$, tensile strength of $3.29 \mathrm{Kpa}$, and film thickness of 0.0754 mm. The optimum concentration of palmitic acid was $4 \%(\mathrm{w} / \mathrm{v})$. This results in the WVTR (Water Vapor Transmission Rate) measurement of 7.99 (g. $\mathrm{mm} / \mathrm{m}^{2}$. hour), film elongation of $1.24 \%$, tensile strength of $3.58 \mathrm{Kpa}$, and film thickness of $0.087 \mathrm{~mm}$.
\end{abstract}

Key Words: ganyong starch, edible film

Diterima: 27 Juli 2004, disetujui: 23 September 2004

\section{Pendahuluan}

Pengemas merupakan bahan yang sangat diperlukan untuk mempertahankan kualitas suatu bahan pangan agar tetap baik, karena bila suatu bahan pangan dibiarkan saja dan berinteraksi dengan lingkungan, seperti adanya kontak dengan uap air dan oksigen, maka bahan pangan tersebut akan cepat rusak, sehingga dapat menyebabkan menurunnya kualitas dan umur simpan dari bahan pangan tersebut. Umumnya jenis pengemas yang sering digunakan adalah plastik. Plastik merupakan bahan pengemas yang dapat mencemari lingkungan karena sifatnya yang non biodegradable, selain itu plastik dapat mencemari bahan pangan yang dikemas karena adanya zat-zat tertentu yang berpotensi karsinogenik yang dapat berpindah ke dalam bahan pangan yang dikemas. Oleh sebab itu perlu dicari bahan pengemas yang memiliki sifat biodegradable dan bersifat seperti plastik (McHugh and Krochta, dalam Krochta et al. 1994).

Salah satu alternatif untuk menggantikan plastik adalah edible film karena sifatnya yang biodegradable dan bertindak sebagai barrier untuk pengambilan oksigen, transfer uap air dan dapat juga sebagai carrier bahan makanan dan aditif tidak berbahaya bila dimakan (Krochta, 1992). Menurut McHugh and Krochta (1994), edible film dibentuk dari biopolimer seperti pati, protein, lemak dan pektin.

Salah satu sumber pati yang dapat digunakan sebagai bahan dasar edible film adalah umbi ganyong. Ganyong merupakan tanaman yang dapat tumbuh di berbagai tempat 
dan dapat hidup sepanjang tahun. Amilosa salah satu penyusun pati, merupakan molekul yang dapat digunakan dalam pembuatan film dan gel yang kuat (Myrna, 1997). Menurut Garcia et al., (1998), amilosa yang tinggi akan membuat film menjadi lebih kompak karena amilosa bertanggung-jawab terhadap pembentukan matrik film. Edible film berbasis pati ini dimodifikasi dengan adanya penambahan gliserol dan asam palmitat. Adanya penambahan gliserol ini akan menghasilkan film yang lebih fleksibel, halus, dapat meningkatkan permeabilitas film tehadap gas, uap air dan zat terlarut (Gontard et al., 1993), sedangkan asam palmitat dapat meningkatkan sifat hidrofobisitas larutan sehingga akan meningkatkan ketahanan terhadap uap air (McHugh dan Krochta, 1994). Tujuan penelitian ini adalah mengetahui dan mempelajari sifat fisik dan mekanik edible film dari pati ganyong dengan adanya penambahan asam palmitat.

\section{Metode Penelitian}

\section{Bahan dan Alat}

Bahan dasar yang digunakan dalam penelitian ini adalah umbi ganyong (Canna edulis Kerr.) yang berasal dari pasar Imogiri Yogyakarta sebanyak $2 \mathrm{~kg}$, sedangkan bahanbahan pembantunya meliputi akuades, gliserol, asam palmitat, alkohol 95\%, HCL 0,02 N, petroleum eter, $\mathrm{H}_{2} \mathrm{SO}_{4}$ pekat, Na-Tiosulfat, asam borat, indikator $\mathrm{PP}, \mathrm{Na}_{2} \mathrm{SO}_{4}, \mathrm{HgO}$, kertas lakmus, silika gel, KOH 0,5 N, HCL 0,1 N, dan reagen yodium.

Alat yang digunakan dalam penelitian ini adalah parutan, ayakan standar Tyler 100 mesh, timbangan elektrik, gelas ukur, gelas beker, pipet ukur, hot plate magnet stirrer, mikrometer, plat kaca $(20 \times 20 \times 2 \mathrm{~cm})$, Universal Testing Instrument (LIoyd Instrument), gunting, tabung reaksi, termometer, gelas pengaduk, botol timbangan, oven, eksikator, labu kjeldahl, alat destilasi kjeldahl, tabung ekstraksi soxhlet, spektrofotometer, labu destilasi soxhlet, dan vortex.

\section{Parameter yang Diamati}

Adapun parameter yang diamati terhadap pati ganyong, meliputi kadar air (AOAC, 1984), kadar abu (AOAC, 1984), kadar protein (AOAC, 1984 ), kadar lemak (AOAC, 1984), kadar amilosa (AOAC, 1984), dan rendemen pati. Karakterisasi edible film meliputi ketebalan film (Gontard et al., 1992), kekuatan regang putus film (Gontard et al., 1992), perpanjangan film (Gontard et al., 1992), dan laju transmisi uap air (Kamper dan Fennema, 1984).

\section{Tahap Pembuatan Pati Ganyong} (Warastuti, 1999)

Umbi ganyong yang sudah dikupas kemudian diparut, dan ditambah air secukupnya setelah itu disaring dan ampasnya dipisahkan (dilakukan ekstraksi berulang dengan cara menambah air pada ampas dan dilakukan penyaringan lagi sampai jernih). Filtrat diendapkan dan dikeringkan dengan penjemuran sinar matahari sampai kering. Pati yang sudah kering diayak dengan menggunakan ayakan 100 mesh sehingga didapatkan pati ganyong. Pati ganyong disimpan dalam wadah gelas yang tertutup, sebelum dipakai untuk keperluan selanjutnya.

\section{Tahap Pembuatan Edible Film (Warastuti,} 1999)

Tahap pembuatan edible film ini ada 2 tahap, yaitu pembuatan edible film dengan variasi konsentrasi pati dan dengan konsentrasi asam palmitat.

a. Pembuatan edible film dengan variasi konsentrasi pati

Edible film dari pati ganyong dibuat dengan cara melarutkan pati ganyong dalam aquadest sebanyak $100 \mathrm{ml}$ dengan kombinasi perlakuan konsentrasi pati ganyong $(1,2,3$ dan $4 \% \mathrm{~b} / \mathrm{v})$. Campuran diaduk dengan hot plate magnetic stirrer dan dipanaskan sampai suhu $70^{\circ} \mathrm{C}$ selama 15 menit. Selanjutnya larutan ditambah plasticizer gliserol sebanyak 30\% (b/b pati). Pemanasan dipertahankan pada suhu $70^{\circ} \mathrm{C}$, sambil dilakukan pengadukan. Pencetakan dilakukan dengan cara menuang 
$100 \mathrm{ml}$ larutan film ke dalam plat kaca yang telah dilapisi mika dengan ukuran $20 \times 20 \times 2$ $\mathrm{cm}^{3}$. Setelah dilakukan pencetakan tahap berikutnya adalah pengeringan dengan menggunakan oven pada suhu $50^{\circ} \mathrm{C}$ selama 10 12 jam. Setelah itu tahap pendinginan selama 10 menit pada suhu ruang, film kemudian dilepas dari plat kaca dan disimpan dalam wadah plastik berisi silika gel, kemudian dilakukan analisis film, yang meliputi analisis ketebalan film, tensile strength film, \% elongasi film, dan laju transmisi uap air film.

b. Pembuatan edible film dengan variasi konsentrasi asam palmitat

Pembuatan edible film dengan variasi konsentrasi asam palmitat ini menggunakan komposisi konsentrasi pati yang menghasilkan sifat-sifat fisik dan mekanik edible film terbaik (dari percobaan a) yaitu dengan WVTR terendah, hasil dari penelitian menunjukkan hasil konsentrasi pati 2\% (karena fungsi utama film adalah menghambat migrasi uap air antara makanan yang dikemas dengan lingkungannya). Variasi konsentrasi asam palmitat yang digunakan adalah 1, 2, 3, 4\% (b/b polimer).

\section{Rancangan Percobaan}

Rancangan percobaan untuk menentukan konsentrasi pati ganyong dan konsentrasi asam palmitat yang optimal adalah Rancangan Acak Lengkap (RAL) dengan empat taraf perlakuan yaitu variasi konsentrasi pati ganyong (Canna edulis Kerr.), dan variasi konsentrasi asam palmitat, serta ulangan dua kali. Analisis statistik lebih lanjut menggunakan ANAVA dan untuk mengetahui beda nyata antarperlakuan digunakan uji Ducan's Multiple Range Test (DMRT) pada taraf kepercayaan $95 \%$.

\section{Hasil dan Pembahasan}

\section{A. Analisis Proksimat Pati Ganyong}

Analisis proksimat yang dilakukan pada pati ganyong meliputi analisis kadar air, kadar abu, kadar amilosa, kadar protein, kadar lemak, dan rendemen. Hasil analisis proksimat pati ganyong dapat dilihat pada Tabel 1.

Tabel 1. Komposisi kimia pati ganyong, pati jagung, dan pati tapioca

\begin{tabular}{lccc}
\hline \hline \multicolumn{1}{c}{ Komponen } & Pati ganyong $^{\mathrm{a}}$ & Pati jagung $^{\mathrm{b}}$ & Pati tapioka $^{\mathrm{c}}$ \\
\hline Air $(\% \mathrm{~b} / \mathrm{b})$ & 10,87 & 10,12 & 12,32 \\
Abu (\% bk) & 0,51 & 0,34 & 0,34 \\
Amilosa $(\% \mathrm{bk})$ & 32,53 & 28,17 & 31,53 \\
Protein $(\% \mathrm{bk})$ & 0,25 & 4,31 & 0,12 \\
Lemak $(\% \mathrm{bk})$ & 0 & 0 & 0 \\
Rendemen $(\%)$ & 14 & 40,20 & 21,87 \\
\hline \hline
\end{tabular}

Keterangan : a : Penelitian (2003), b : Imelda (2003), c : Warastuti (1999)

Pembuatan edible film dari bahan dasar pati komponen utama yang sangat diperlukan untuk membentuk matriks film adalah amilosa. Menurut Myrna (1997), amilosa dapat digunakan untuk pembuatan film dan gel yang kuat. Berdasarkan hasil analisis proksimat pati ganyong, menunjukkan hasil bahwa kadar amilosa lebih tinggi dari $30 \%$ (32,53\%), sedangkan kandungan amilosa pati jagung
$28,17 \%$, dan kandungan amilosa pati tapioka 31,53\%. Pada Tabel 1 terlihat bahwa kandungan amilosa pati ganyong lebih tinggi bila dibandingkan dengan pati-pati yang lain. Menurut Garcia et al., (1998), kadar amilosa yang tinggi akan membuat film menjadi lebih kompak, karena amilosa bertanggung-jawab dalam pembentukan matriks film. 
B. Pengaruh Konsentrasi Pati Ganyong terhadap Sifat Fisik dan Mekanik Edible film

Ketebalan film yang dihasilkan pada penelitian ini dengan variasi konsentrasi pati ganyong berkisar antara 0,0329-0,097 $\mathrm{mm}$ seperti terlihat Gambar 1. Ketebalan film tertinggi pada konsentrasi pati ganyong 4\% yaitu $0,097 \mathrm{~mm}$, sedangkan yang terendah pada konsentrasi pati ganyong $1 \%$ yaitu $0,0329 \mathrm{~mm}$.

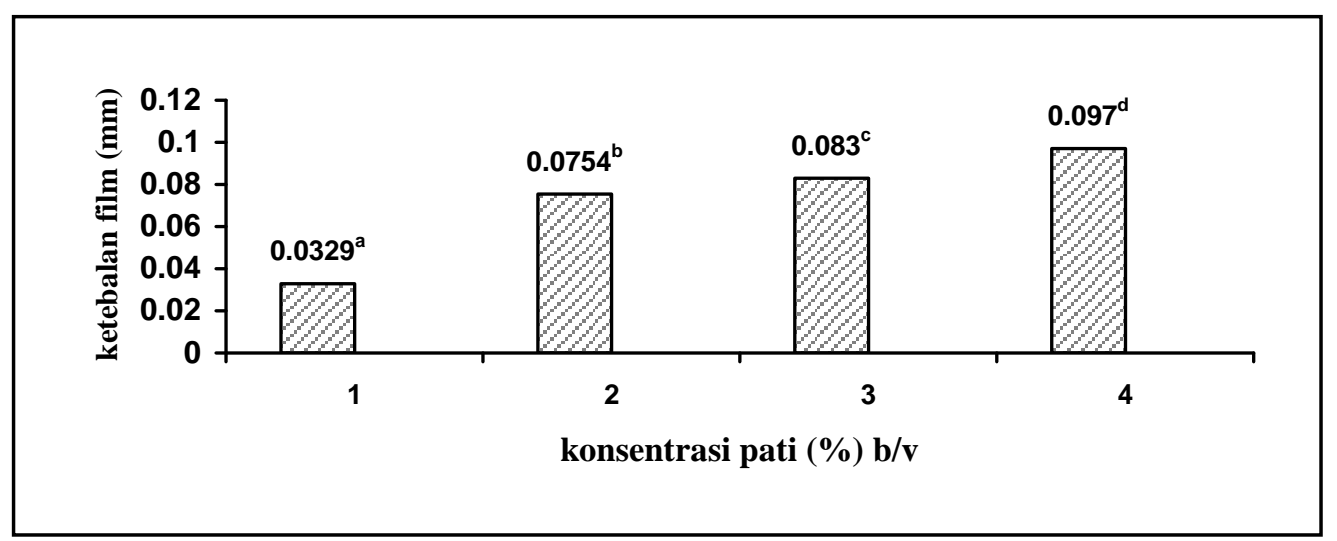

Gambar 1. Ketebalan edible film pada variasi konsentrasi pati ganyong

Tensile strength merupakan gaya maksimum yang diperlukan untuk memutuskan atau menyobek film selama pengujian kekuatan regang putus (Briston, 1988). Kekuatan regang putus film yang dihasilkan berkisar antara 1,34125-8,4676 Kpa. Kekuatan regang putus film tertinggi pada konsentrasi pati ganyong 4\% yaitu 8,4676 Kpa, sedangkan yang terendah pada konsentrasi pati ganyong $1 \%$ yaitu 1,34125 Kpa. Semakin tinggi konsentrasi pati ganyong yang ditambahkan maka kekuatan regang putus film yang dihasilkan cenderung meningkat seperti terlihat pada Gambar 2. Hal ini disebabkan semakin banyak pati yang digunakan maka mengakibatkan semakin rapat matriks film yang terbentuk, sehingga gaya yang diperlukan untuk menarik film hingga putus lebih besar, adanya kenyataan tersebut maka akan berdampak pada peningkatan nilai tensile strength edible film.

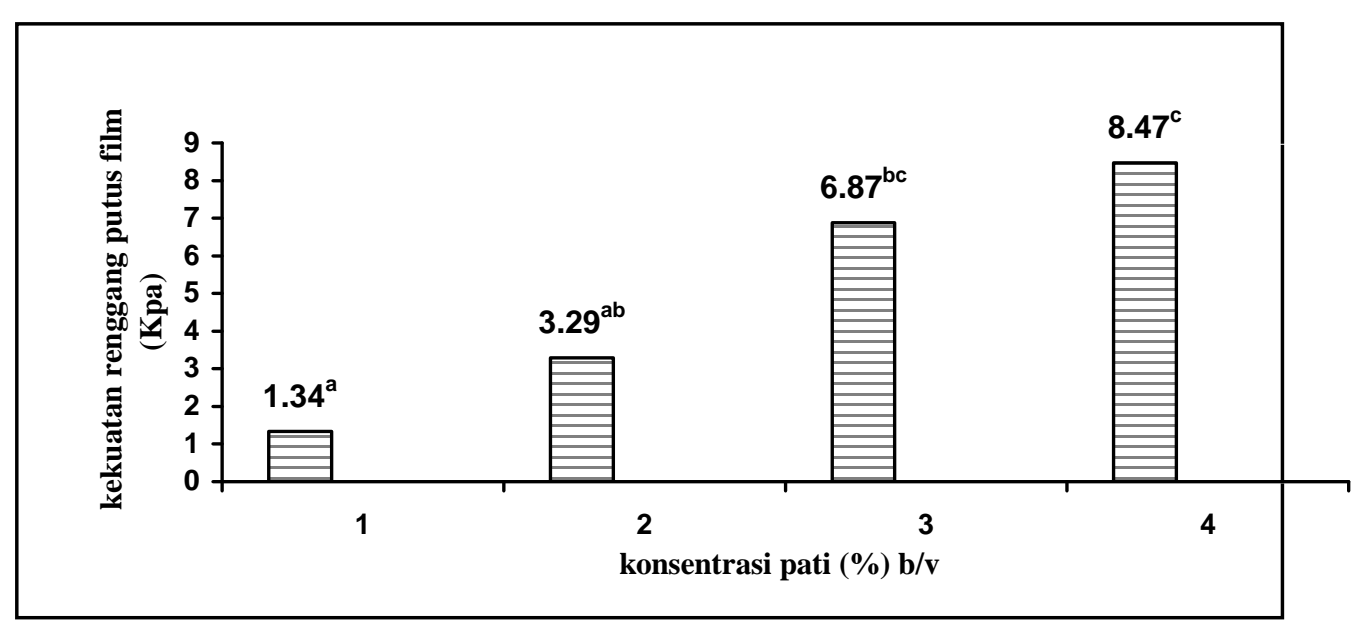

Gambar 2. Kekuatan regang putus film pada variasi konsentrasi pati ganyong 
Persentase perpanjangan adalah perubahan panjang maksimum yang dialami film pada saat pengujian kekuatan regang putus pada saat film sobek. Persentase perpanjangan edible film berkisar antara 1,484 - 2,891\% seperti terlihat pada Gambar 3.

Hasil analisis menunjukkan persentase perpanjangan film tertinggi yaitu $2,891 \%$ pada konsentrasi pati $4 \%$, sedangkan yang terendah pada konsentrasi pati $1 \%$ yaitu $1,484 \%$. Nilai elongasi edible film akan naik seiring dengan meningkatnya konsentrasi pati. Peningkatan konsentrasi pati lebih lanjut menyebabkan peningkatan matriks film yang dibentuk melalui ikatan intermolekuler antarpolimer pati. Amilosa memiliki struktur rantai lurus yang memudahkan pembentukan ikatan tiga dimensi yang dapat membentuk gel yang kuat, sehingga film yang dihasilkan tidak rapuh.

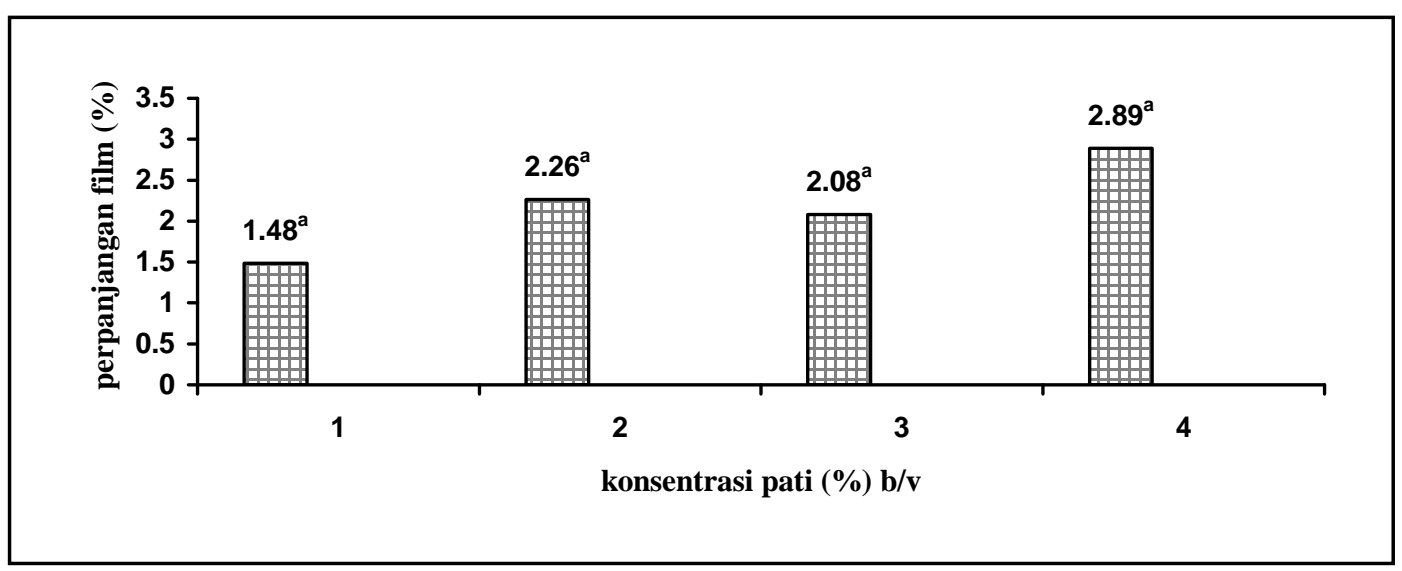

Gambar 3. Perpanjangan edible film pada variasi konsentrasi pati ganyong

Water vapor trasmission rate didefinisikan sebagai kecepatan perpindahan uap air melalui suatu unit area dari material rata dengan ketebalan tertentu yang disebabkan oleh perbedaan tekanan diantara dua permukaan yang spesifik, pada temperatur dan kelembaban tertentu (Anonim, 1980). Water vapor trasmission rate yang dihasilkan dalam penelitian ini berkisar antara 11,86 - 18,17 (g.mm $/ \mathrm{m}^{2}$.jam) seperti terlihat pada Gambar 4. Nilai tertinggi diperoleh pada konsentrasi pati ganyong $1 \%$ yaitu $18,17 \quad\left(\mathrm{~g} . \mathrm{mm} / \mathrm{m}^{2}\right.$.jam), sedangkan terendah pada konsentrasi pati ganyong $2 \%$ yaitu $11,86 \quad$ (g.mm $/ \mathrm{m}^{2}$.jam) Menurut Pranata et., al., (2002) edible film pati batang aren menghasilkan WVTR yang paling kecil adalah 28,27 (g. mm/m². jam).

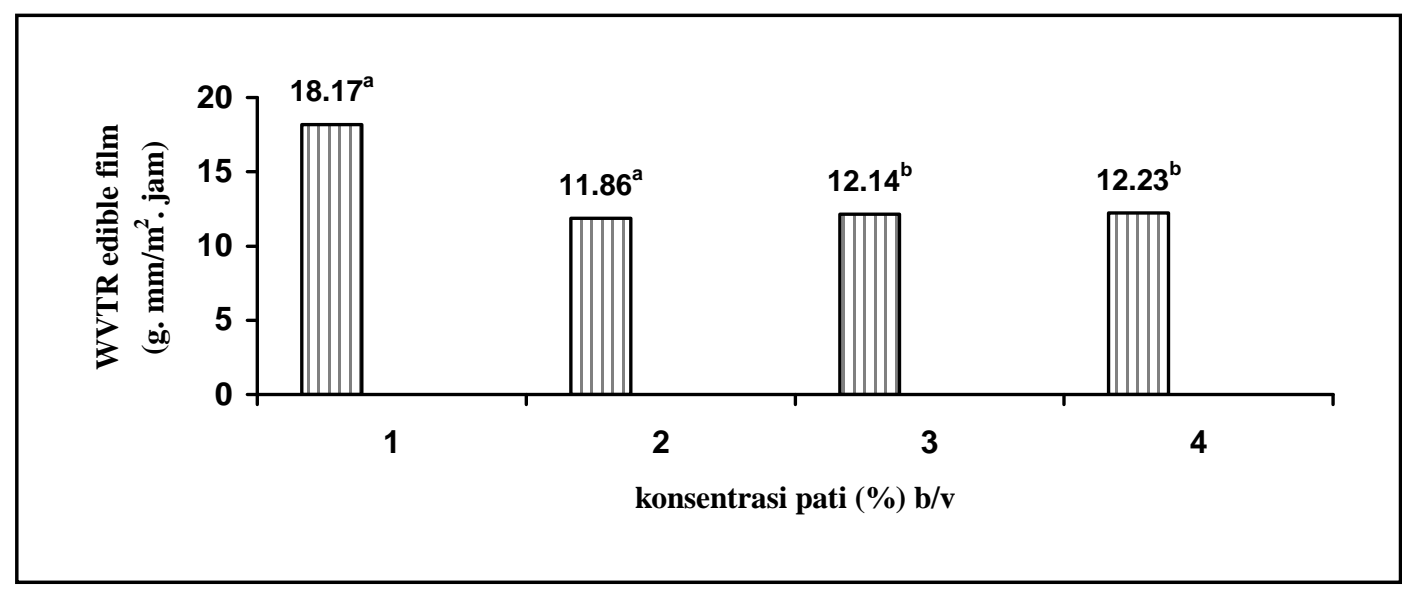

Gambar 4. WVTR film pada variasi konsentrasi pati ganyong 


\section{Pengaruh Konsentrasi Asam Palmitat terhadap Sifat Fisik dan Mekanik Edible film pati ganyong}

Pengaruh penambahan asam palmitat dapat dilihat Gambar 5. Konsentrasi pati yang digunakan dalam pembuatan edible film dengan penambahan asam palmitat ini adalah komposisi konsentrasi pati dengan edible film yang mempunyai WVTR terendah yaitu dengan konsentrasi pati $2 \%$ (ketebalan filmnya 0,0754 mm). Ketebalan edible film dengan adanya penambahan asam palmitat berkisar antara 0,076-0,087 mm. Apabila dibandingkan antara film (konsentrasi pati 2\%) dengan film yang ditambah asam palmitat, maka film dengan adanya penambahan asam palmitat lebih tebal. Hal ini disebabkan oleh jumlah padatan dalam larutan pembentuk film, semakin banyak jumlah padatan terlarutnya maka film yang dihasilkan akan semakin tebal. Ketebalan film tertinggi diperoleh pada konsentrasi $4 \%$ asam palmitat yaitu $0,087 \mathrm{~mm}$, sedangkan yang terendah pada konsentrasi $1 \%$ asam palmitat yaitu $0,076 \mathrm{~mm}$.

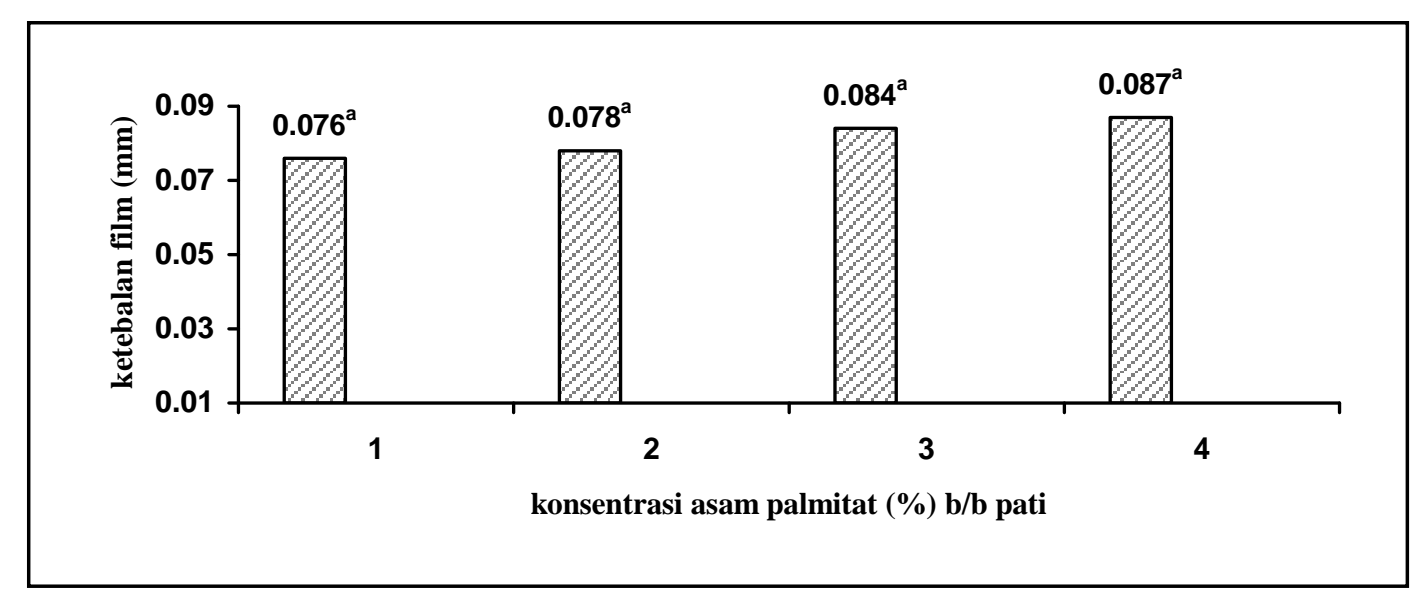

Gambar 5. Ketebalan edible film pati ganyong pada variasi konsentrasi asam palmitat

Berdasarkan Gambar 6, kekuatan regang putus edible film berkisar antara 2,92915-3,5802 Kpa. Kekuatan regang putus film tertinggi diperoleh pada konsentrasi asam palmitat $4 \%$ yaitu 3,5802 Kpa, sedangkan yang terendah pada konsentrasi $2 \%$ asam palmitat yaitu 2,2781 Kpa. Semakin tinggi konsentrasi asam palmitat yang ditambahkan maka akan meningkatkan kekuatan regang putus edible film, akan tetapi saat mencapai titik kritisnya penambahan asam palmitat tersebut akan menurunkan kekuatan regang putus film. Hal ini sesuai Lai dan Huey (1997), bahwa adanya penambahan asam palmitat akan terbentuk kompleks amilosa-asam palmitat, sehingga menyebabkan film lebih kompak dan akan meningkatkan kekuatan regang putus film akan tetapi saat mencapai titik kritisnya penambahan asam palmitat tersebut akan menurunkan kekuatan regang putus film.
Persentase perpanjangan yang dihasilkan berkisar antara 1,244-18,82 \%. Persentase perpanjangan tertinggi diperoleh pada penambahan konsentrasi asam palmitat $1 \%$ yaitu $18,82 \%$, sedangkan terendah pada penambahan konsentrasi asam palmitat 4\% yaitu 1,244\%. Menurut Gontard et al., (1993), asam-asam lemak memiliki sifat sebagai anti plasticizing pada film yang dibuat dari gluten. Sifat anti plasticizing asam palmitat pada edible film pati ini disebabkan karena terbentuk kompleks amilosa-asam lemak yang akan menambah kepaduan jaringan tiga dimensi polimer film, sehingga menurunkan tingkat perpanjangan seperti terlihat pada Gambar 7. Menurut McHugh dan Krochta (1994), film yang terbentuk dari pati yang memiliki kompleks amilosa-asam lemak akan memiliki tingkat elongasi yang lebih rendah dibandingkan dengan tidak memiliki ikatan kompleks amilosa-asam lemak. 


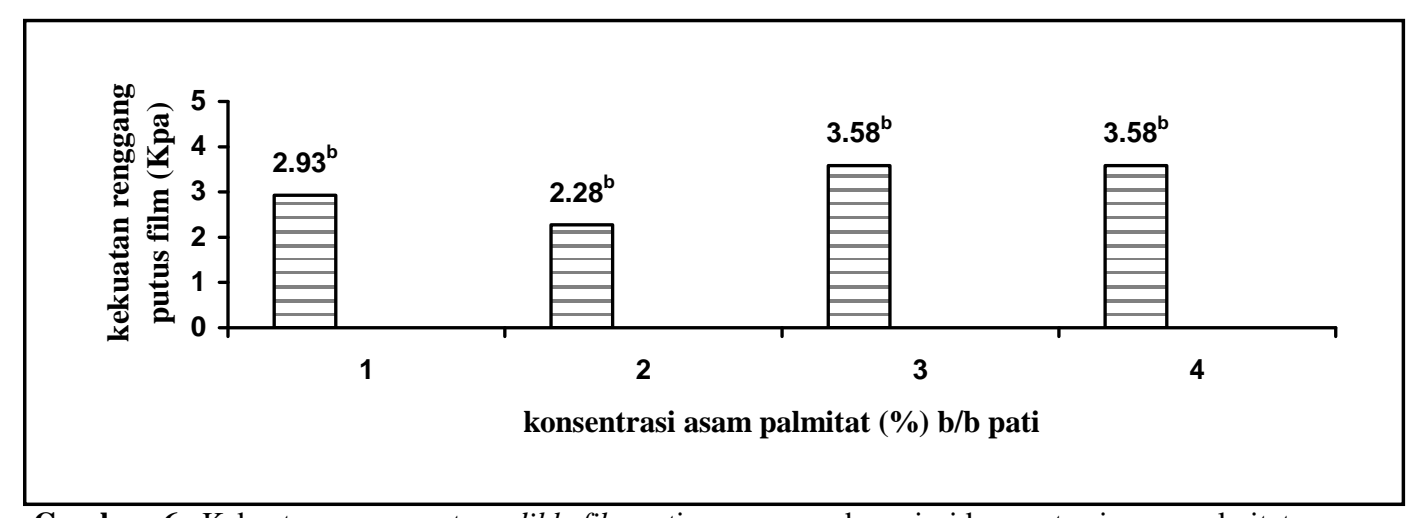

Gambar 6. Kekuatan regang putus edible film pati ganyong pada variasi konsentrasi asam palmitat

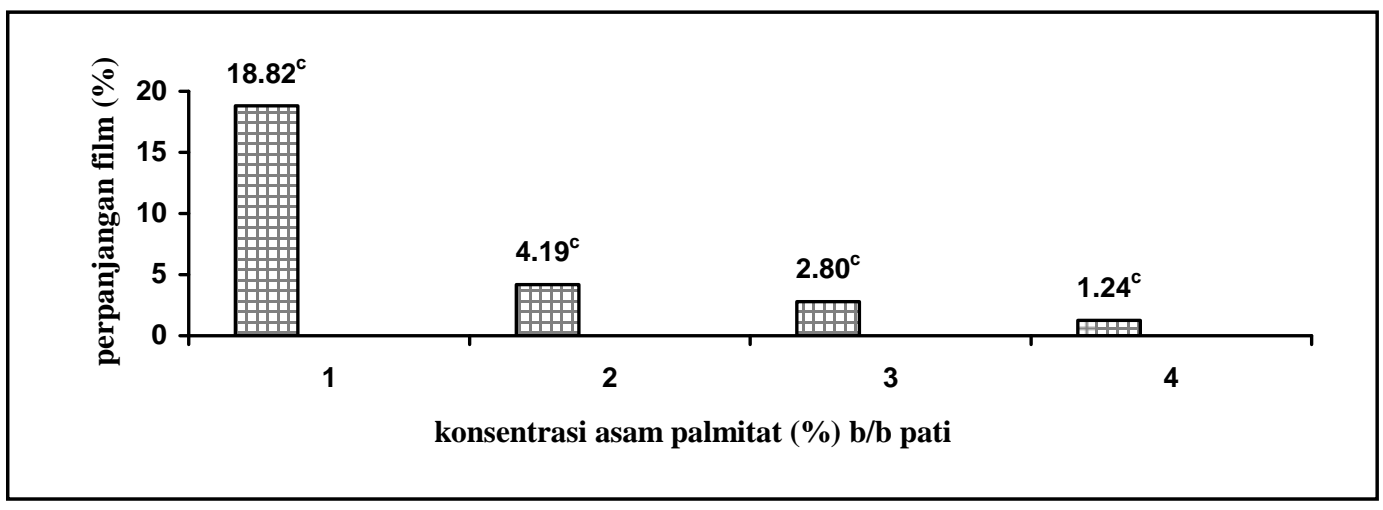

Gambar 7. Perpanjangan film pati ganyong pada variasi konsentrasi asam palmitat

Seperti terlihat pada Gambar 8, WVTR terbesar dihasilkan dari film dengan penambahan konsentrasi asam palmitat $1 \%$ yaitu 8,9419 (g. $\mathrm{mm} / \mathrm{m}^{2}$. jam), sedangkan yang terkecil dari film dengan penambahan konsentrasi asam palmitat $4 \%$ yaitu 7,98835 (g. $\mathrm{mm} / \mathrm{m}^{2}$. jam). Kisaran WVTR edible film yang dihasilkan yaitu 7,98835 - 8,9419 (g. mm/m². jam). Pranata et al., (2002) melaporkan bahwa edible film pati batang aren dengan penambahan asam palmitat $0-10 \%(\mathrm{~b} / \mathrm{b}$ pati), menghasilkan WVTR yang paling kecil sebesar 24,60 (g. $\mathrm{mm} / \mathrm{m}^{2}$. jam). Hasil analisis WVTR edible film semakin menurun dengan meningkatnya konsentrasi asam palmitat yang ditambahkan. Menurut Krochta dan Johnson (1997), peningkatan jumlah rantai asam lemak akan menurunkan laju transmisi uap air film.

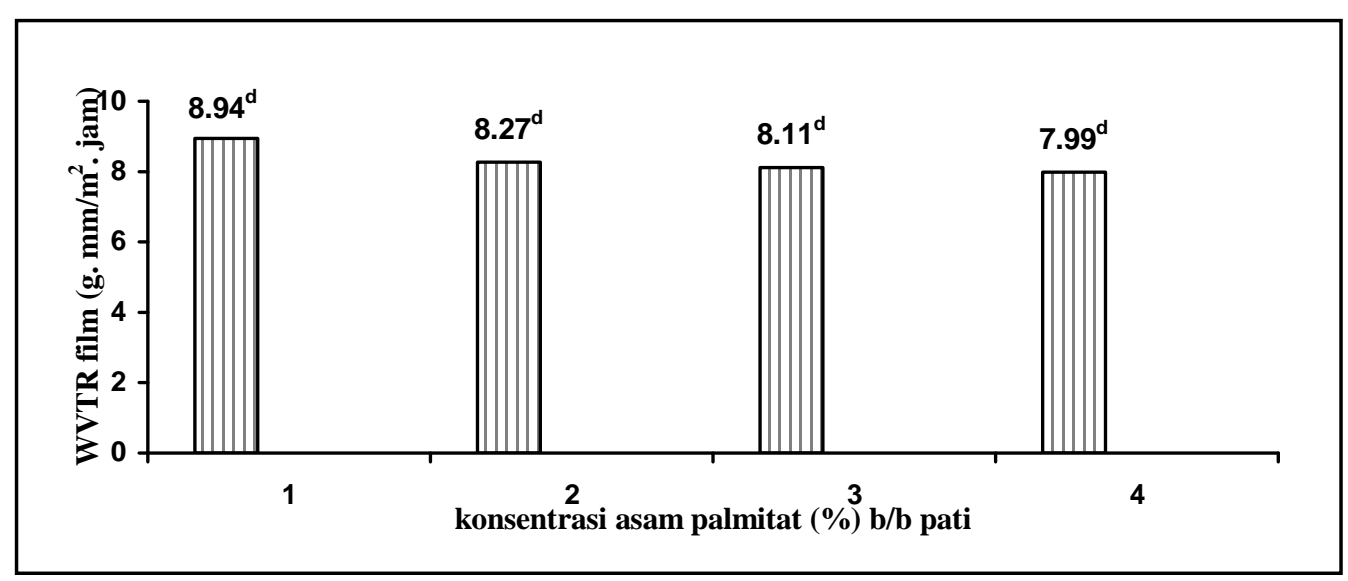

Gambar 8. WVTR film pati ganyong pada variasi konsentrasi asam palmitat 


\section{Kenampakan Edible Film dengan Penambahan Asam Palmitat}

Berdasarkan kenampakan edible film yang dihasilkan, film dengan penambahan asam palmitat tampak tidak transparan bila dibandingkan dengan film tanpa adanya penambahan asam palmitat. Hal ini menunjukkan bahwa semakin tinggi asam palmitat yang digunakan, maka film yang dihasilkan akan semakin buram dan kasar. Kenampakan film yang tidak transparan dan kasar ini disebabkan oleh asam palmitat yang tidak dapat terperangkap di dalam struktur heliks amilosa.

\section{Kesimpulan}

Berdasarkan hasil penelitian yang diperoleh, maka dapat disimpulkan bahwa pati ganyong memiliki kandungan amilosa 32,53\%, sehingga dapat digunakan sebagai bahan dasar pembuat edible film. Konsentrasi pati ganyong yang optimal untuk pembuatan edible film dimana memberikan pengaruh terhadap sifat fisik dan mekanik edible film adalah konsentrasi pati $2 \%$. Konsentrasi asam palmitat yang optimal untuk pembuatan edible film dimana memberikan pengaruh terhadap sifat fisik dan mekanik film adalah konsentrasi asam palmitat $4 \%$.

\section{Daftar Pustaka}

Anonim, 1980. Standard Test Methods for Water Vapor Transmission of Material, Standard Designation : E96-80. In Annual Book of ASTM. ASTM, 771-778. Philadelpia.

AOAC, 1984. Official Methodes of Analysis of the Association of Offisial Analysis, Chemist 14 th, ed AOAC, Inc, Arlington Verginia.

Briston, J. H. 1988. Plastic Films, $3^{\text {rd }}$ Edition, John Wiley dan Sons Inc.

Garcia, M. A., Martino, M.N. and Zaritzky, N.E. 1998, Plastized Starch-Based to Improve Strawberry (Fragaria x Ananassa) Quality and Stability. $J$ Agric. Food Chem. 46 (9): 3758-3767.
Gontard, N., Guilbert, S. and Cuq, J.L. 1992. Edible Wheat Glutein Film, Inflence of The Main Process Variabels on Film Properties Using Response Surface Methodology, J. Food Sci. 57 (1) : 190-195, 199.

Gontard, N., Guilbert, S. and Cuq, J.L. 1993. Water and Glicerol as Plasticizers Effect Mechanical and Water Vapour Barrier Properties of an Edible Wheat Glutein Film, J. Food Sci., 58 (1) : 206211.

Imelda, R.T., S, 2003, Pengaruh Konsentrasi Sorbitol dan Asam Palmitat terhadap Sifat Fisik dan Mekanik Edible Film Pada Variasi Kadar Pati Jagung (Zea mays L.). Skripsi Fakultas Biologi, UAJY Yogyakarta.

Kamper, S.L., and Fennema, O., 1984, Water Vapour Permeability of Edible Films, J. Food Science, 49: 1478.

Krochta, J. M. 1992. Control of Massa Transfer in Food With Edible Coating and Film in: Sing, R. P. Wirakarta Kusumah (ed)., Advances in Food Engineering, CRC, Press. Boca Reton.

Krochta, J.M. and C.M. Johnson. 1997. Edible and Biodegradable Polymer Film Challenger and Opportunities, Food Tech, 51 (2): 61-74.

Lai and Huey. 1997. Properties of Microstructures of Sheets Plasticized with Palmitic Acid, J. cereal Chemiestry 42(4).

Myrna, O.N.C. 1997. Edible Coating and Films Based on Polisaccarides in J.M. Krochta, E.A. Baldwin and M.O. Nisperos-Carriedos (eds), Edible Coating and Films to Improve Food Quality, Technomic Publ. Co. Inc. Lancaster, Basel.

McHugh, T.H. and Krochta, J.M. 1994. Permeability Properties of Edible Films, in Krochta, J. M., E. A. Baldwin and M. O. Nisperos-Carriedo (Eds), Edible Coating and Film to Improve Food Quality, Technomic Publ. Co. Inc., Lancester, Basel.

Pranata F. S., Marseno, D.W. dan Haryadi. 2002 Karakterisasi Sifat-Sifat Fisik dan Mekanik Edible Film Pati Batang Aren (Arenga pinnata Merr.) J. Food Sci (3): 121-130.

Warastuti, M., 1999, Pengaruh Penambahan Sorbitol dan Asam Palmitat terhadap Sifat Fisik dan Mekanik Edible Film dari Pati Ubi Kayu, Skripsi Fakultas Teknologi Pertanian, UGM, Yogyakarta. 